JURNAL AL BAYAN: JURNAL JURUSAN PENDIDIKAN BAHASA ARAB

\title{
Competency-Based Syllabus and Skills-Based Syllabus of Arabic Learning in College
}

\author{
Nuraini \\ Prodi Pendidikan Agama Islam Universitas Muhammadiyah Ponorogo, Indonesia
}

\section{Article History:}

Received : March 1 $1^{\text {st }}, 2019$

Revised : April $7^{\text {th }}, 2019$

Accepted : May $15^{\text {th }}, 2019$

Published : June $1^{\text {st }}, 2019$

Keywords:

Arabic; Competency; Skill Syllabus

* Correspondence Address:

nuraini@umpo.ac.id

\begin{abstract}
A challenging and uncertain millennial era requires that educational institutions design their education based on real needs in the field capable of producing human resources with attitude, knowledge and skill competencies, in order to prepare this, syllabus plays an important role because it is one of the stages of the curriculum, to answer what to learn to deal with this problem. Competence can be interpreted as knowledge, skills, and abilities controlled by someone who has become part of himself. So that he can perform cognitive, affective and psychomotor behaviors as well as possible. This study uses a development research method developed by Jack Richard which modified according to the needs in the development of the syllabus. Thus, the research steps include the study of documents on the syllabus that is already running, observation of learning using a running syllabus, and analysis of needs for the development of the syllabus, and developing the syllabus for Arabic language learning in higher education. The skillbased syllabus contains a number of specific "predictable" abilities to be part of language usage. Skill-based syllabus organizes materials around the language skills or academic skills that students need to learn the language. further this article present kind and function of syllabus, its also discuss about how to organizing materials to reach goals of arabic learning, and also doscuss some problem encountered in the implementation of the syllabus.
\end{abstract}

\section{Introduction}

The development of Educational World and social society in this era is compared with the various challenges which must be faced by the educational world. In line with this, the educational world must be prepared for the quality of the graduates who can compete in the era of change and uncertainty. The college should be able to design the education which appropriates with the students' need in society and also able to pass 
human resources who are competence in aspects of attitude, knowledge, and skills. ${ }^{1}$ The process of learning in the educational institution must be able to emphasize the students as the subject of learning, so it hopes that from the educational institution not only produces the graduate students who rich of theory but also have competence for implementing their knowledge.

Arabic language occupies a prominent position among the languages of the world, which is growing demand for learning day after day, and has become concerned with education to work to improve the methods of education, and the development of educational programs. ${ }^{2}$ learning Arabic in Indonesia has not shown satisfactory results because of several factors such as a curriculum that has not yet represented the aspects that students need comprehensively, the instructor, namely the lack of readiness of the teacher and the practice of teaching. ${ }^{3}$ Arabic learning is the important learning in getting the skills of listening, speaking, reading and writing. Besides that, Arabic learning in college aims to help the students to get the skills through various forms and language in communication activity. Based on this goal, the teacher/ linguist must review the curriculum according to the students' needs, determining the learning material then arranging the learning process by the method and learning strategy.

The learner even its teacher or lecturer in an educational institution (school and college) not only giving the material to the students but also must provide a new vehicle and doing the innovation in learning. The learner must be able put the process of learning as an agent of modernization in the whole field and must have a vision about what is done for the learner, the reason to doing the activity which consists of why doing the activity and how to implement them in learning. Jack Richard states that the development of the curriculum must begin from the input, process, and output. ${ }^{4}$ In language learning, input refers to the linguistic content from a course. So, before teaching language, the learning objectives should be clear and real, then determining the learning material that will be delivered and is arranged in the rational sub. Through this process, it will produce the syllabus as a guide in a learning activity to achieve the objectives of Arabic learning.

\footnotetext{
1 Abdul Madjid And Chaerul Umam, Pendekatan Ilmiah Dalam Implementasi Kurikulum 2013 (Bandung: Pt. Remaja Rosda Karya, 2015).

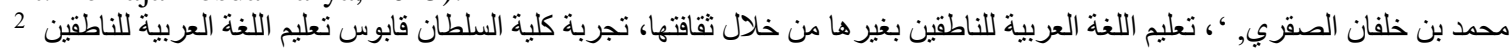
بغير ها-سلطنة عمان (Malang: Imla, 2015), P. 1.

${ }^{3}$ Muhammad Syaifullah, 'Kajian Teoritis Pengembangan Bahan Ajar Bahasa Arab', Arabiyatuna Jurnal Bahasa Arab, 3.1 (2019), 127-44 <Https://Doi.Org/Http://Dx.Doi.Org/10.29240/Jba.V3i1.764>.

4 Jack C. Richards, 'Curriculum Approaches In Language Teaching: Forward, Central, And Backward Design', Relc Journal, 2013 <Https://Doi.Org/10.1177/0033688212473293>.
} 
The syllabus is an important component in determining the success of the learning process. syllabus sets the onward responsibilities of teacher to student. ${ }^{5}$ Through the appropriate syllabus, teachers and students will be easier achieving the learning objectives as determined in the curriculum. The syllabus is an important information source for the students as the reference in learning to strengthen the objectives, role, attitude, and strategy used by the teacher in getting active, effective and useful learning.

The educational institution basically has an authority to develop syllabus appropriate with the students' need. In arranging the syllabus there is some design that reflects a different understanding from the character of language and the view for emphasizing the language ability such as vocabulary, structure, function, or kinds of text. The criteria for selecting the syllabus units include frequency, usability, simplicity, learning, authenticity.

The research on developing the syllabus still very small, especially in Arabic learning. The teachers are also not maximal in innovating the development of the Arabic syllabus. One of the research about the development of the syllabus done by Yumna Rasyid was starting by analyzing the students' need who followed the Arabic writing skill in UNJ. Analyze the need also done to the lecturer and students who taught Arabic. In addition, the researcher also studied the syllabus document used. Based on the result and needs analysis obtained finding that underlie the development of Arabic syllabus on writing skill. ${ }^{6}$ Based on the research above, it can be concluded that in the development of the syllabus, the analysis of the needs of the users must be carried out, in this case, the lecturers and the target parties, namely students. Regarding this, the development of the syllabus is necessary because it one of the important stages in the curriculum to answer the question " what should be learned in a program?" In this occasion, the writer will try to discuss Competency-based Syllabus and Skill based Syllabus in Arabic learning at college.

\footnotetext{
${ }^{5}$ Mariana Ulfah Hosney, 'From Syllabus To Curriculum Development', Jurnal Linguistik Terapan, 3.1 (2013) <Https://Jlt-Polinema.Org/?P=379>.

${ }^{6}$ Nurhayati, 'Pengembangan Silabus Pembelajaran Bahasa Indonesia Untuk Sekolah Menengah Pertama Di Kota Palembang', 91 (2017), 399-404.
} 


\section{Theoretical Support}

\section{The Definition of Syllabus}

Brown stated that the syllabus is ways to organized teaching and material. Wilkins stated the syllabus is a content specification of the language teaching that has been selected and arranged based on the stages with the aim of making the learning process more effective. According to the definitions, it can be concluded that the syllabus is a plan of learning program that makes the concept that will learn, how the selection, how the arrangement and implementation for achieving the aim of the learning that has been determined.

Besides that, the word syllabus also known as the curriculum. Dubin dan Olshtain (in Krahnke) stated that the syllabus is more specific and concrete than the curriculum. According to Nunan, the curriculum has a wider scope because it refers to the whole aspects such as planning, implementing, assessing, and the rule of the learning program. The curriculum is contained of some syllabus. Syllabus relates to efforts to provide and provide guidelines or guidelines for lecturers to carry out teaching and learning, both in the classroom and outside the classroom, so that the goals set can be realized. These efforts can be carried out by several parties, such as lecturers both individually and in groups, educational program administering institutions, or the government. ${ }^{7}$

Syllabus is composed of linguistic structures, so language teaching must be based on a syllabus arranged according to the point of view of grammar. the type of syllabus will become the distinguishing character of an Arabic teaching method. ${ }^{8}$ syllabus contains several components, namely: syllabus identity, synopsis of courses, learning outcomes, indicators of achievement, learning, topics / sub-topics, and references. ${ }^{9}$ The syllabus is a reference for the teacher in arranging a lesson plan and in implementing a learning process.

\section{The Principles of Arrange Syllabus}

7 Suratmi, 'Penelitian Dan Pengembangan Silabus Bahasa Inggris Program Studi Penerbitan', Jurnal Publipreneur, 2.4 (2014), 115 <Https://Text-Id.123dok.Com/Document/Yjoewxmz-Penelitian-DanPengembangan-Silabus-Baha-2.Html>.

8 Aziz Fahrurrozi, 'Pembelajaran Bahasa Arab: Problematika Dan Solusinya', Arabiyat: Jurnal Pendidikan Bahasa Arab Dan Kebahasaaraban, 2015 <Https://Doi.Org/10.15408/A.V1i2.1137>.

9 Syafruddin Nurdin, 'Pengembangan Kurikulum Dan Rencana Pembelajaran Semester (Rps) Berbasis Kkni Di Perguruan Tinggi', Al-Fikrah: Jurnal Manajemen Pendidikan, 2019 <Https://Doi.Org/10.31958/Jaf.V5i1.813>. 
According to Harmer, there are some criteria that should be considered as basic in arranging the syllabus. Those are ${ }^{10}$

1. Learnability, this is related to the ease or no structure and certain of lexical items by the students.

2. Frequency, Related to the items of language that often use in the language.

3. Coverage, some of the words and grammatical structures include the most common use than the word and other grammatical.

4. Usefulness, Related to what the certain lexical items is nearer from the students' lives so it is more useful for the students.

5. Systematic

The syllabus components are related functionally in achieving competence. ${ }^{11}$ Consistent

The existence of a consistent relationship (steady, obedient principle) between basic competencies, indicators, subject matter, learning experience, learning resources, and assessment system.

6. Actual and Contextual

The scope of indicators, subject matter, learning experience, learning resources, and assessment systems pay attention to the development of the latest science, technology, and art in real life, and events that occur.

7. Comprehensive

The syllabus component covers the entire domain of competence (cognitive, affective, psychomotor).

Based on the explanation above, the syllabus must arrange through various aspects such as the level of difficulties, usage, wider scopes and appropriate with the needs of students in daily communication.

\section{The Component of Syllabus}

Syllabus is the elaboration of standard competencies and basic competencies into subject matter / learning, learning activities, and indicators of achievement of

\footnotetext{
10 Jeremy Harmer, The Practice Of English Language Teaching (Harlow Essex: Pearson Education Limited, 2001).

11 Bani, 'Pengembangan Silabus Dan Rencana Pelaksanaan Pembelajaran Dalam Meningkatkan Profesionalisme Guru', Jurnal Pendidikan, Komunikasi, Dan Pemikiran Hukum Islam, 6.2 (2015), 198209 <Https://Ejournal.Iaida.Ac.Id/Index.Php/Darussalam/Article/View/73>.
} 
competencies for assessment. ${ }^{12}$ In preparing the syllabus must pay attention to several components as follows. ${ }^{13}$ Competency standards: that can be performed or displayed on a subject

1. Basic competencies: are minimal competencies that can be carried out by students in a subject

2. Indicators: characteristics, signs, actions or responses that must be done by students to show that they have certain basic competencies

3. Subject matter / learning: teaching materials that students must learn to master basic competencies

4. Learning activities: experiences or activities that students need to do to master basic competencies or learning material

5. Assessment: an activity to determine the quality or value of a program in which there is an element of 'decision making' so that it contains an element of subjectivity

6. Time allocation provided for subjects during education at the education unit level

7. Learning resources: everything that can be used to give experience to someone who learns, either directly or indirectly, in part or in whole.

According to the description then in preparing the syllabus must include competency standart, Basic Comptency, Indicators, Subject Matters. Learning Activity, Assesment, Time Allocation and learning resources.

\section{The Kinds of Syllabus Design}

\section{Structural Syllabus}

The structural syllabus is the language learning syllabus with the target that focuses on the rules of language and provides the units of learning in form of presenting the certain grammatical aspect series. ${ }^{14}$ Thuaimah also stated that structural syllabus is a type of syllabus that presenting language material in form of discussion around grammatical themes.

This syllabus is based on two basic assumptions. The first, language is a system (structure). The language system includes the groups of grammatical that if it learned by

\footnotetext{
12 Syaiful Sagala, 'Silabus Sebagai Landasan Pelasanaan Dan Pengembangan Pembelajaran Bagi Guru Yang Profesional', Tabularasa, 5.1 (2008), $11<$ Http://Digilib.Unimed.Ac.Id/714/>.

13 Ahmad Zubaidi, 'Model-Model Pengembangan Kurikulum Dan Silabus Pembelajaran Bahasa Arab', Cendekia: Jurnal Kependidikan Dan 2016 <Https://Doi.Org/10.21154/Cendekia.V13i1.240>.

${ }^{14}$ Muhammad Ali Al-Khuli, A Dictionary Of Applied Linguistics: English-Arabic With An Arabic-English Glossary, 1st Edn (Lebanon: Librairie Du Lian, 1986).
} 
someone he will be able to use language. The second, each meaning has certain language structure so, in learning language, it needs to determine the various structure that can transfer various meaning that makes the communication process easier. Some of the terms that generally use in syllabus structural as follows ${ }^{15}$ :

a. Sentence Pattern (أنماط الجملة), that is the style of the sentence which the meaning is presented.

b. Grammatical themes (موضو عات النحو), that is the grammatical concept related to the language structure which arranged in certain chapters.

c. Sentence' structure (التركيب اللغوي), that is a matrix that expresses the sentence. In this case, can be stated a structure of the sentence as the structure of faa'il $+f a a^{\prime} i l+m a f^{\prime} u l b i h$.

d. Total, that is the expression that can be understood the meaning.

The structural syllabus is usually used in the grammatical-translation method.

\section{Situational Syllabus}

The situational syllabus is contained of the group of situations, whether it real or imaginary, where the language takes place or used. ${ }^{16}$ There are two kinds of the situational syllabus, those are, (1) situational syllabus of imaginer/manipulative and (2) syllabus that comes from the empirical data in the field. In the imaginer syllabus language structure is taught in the middle of its situations learning. The second kinds of situational syllabus come from the basic assumption that language is social phenomena which appear as the tools of communication between fellow human.

Experts try to predict the situations that may be faced by the students in communicating in daily life through field studies or research. After known the situations which predict will face by the students so the next stage is selecting language material that appropriates to the students' communication needs. This syllabus can motivate the students for continuing their language study because it makes the learning process is meaningful.

\footnotetext{
${ }^{15}$ Rusdi Ahmad Thuimah, Ta'lim Al Arabiyah Li Ghairi An Nathiqiina Biha Wa Asaliibihi (Ar Ribath: Mansuuratu Al Munadhamah Al Islamiyyah Lii At Tarbiyah Wa Al'ulum Wa Atsaqofah, 1989).

16 Thuimah.
} 


\section{National Syllabus/ Functional}

The national syllabus according to Al khuli is syllabus which based on the functions of language as the substitute for the rule units and situation. ${ }^{17}$ According to Karl Krahnke situational syllabus is a syllabus where the content of language learning is the group of functions that will perform when the language use or the group of ideas that will express by language.

This syllabus is based on the consideration of communication ability as the main basis of development. The selecting of material is done as the meaning of the students' needs in the communication process. Thus, "meaning" and not structure or situation is to determine the language material. But, this case is a consequence the variety of language structure or language situation that appropriate to the variety of ideas.

Wilkins, the person who introduced this syllabus, divided the ideas to become some big units and several smaller sub-units. Wilkins stated that some of the big units are: time, number, place, the meaning of relationship, related to the amount spoken in its context.

\section{Method}

This research used development research which developed by Jack Richard with the following stages: (1) an analysis of the needs to the development of syllabus (2) an analysis of situation is collection of information that includes document study to the syllabus that is running and the implementation of the observation, the collection of information to the result of the learning with the syllabus that is running and the needs analysis(3) The planning of learning outcome(4) The organization of learning design(5) determining the learning material(6) Designing the active learning and (7) evaluating. ${ }^{18}$ The seven stages are modified as the needs in developing a syllabus. Thus, the stage of the research includes document study to the syllabus that is running, learning observation by using the running syllabus and analysis the needs for developing the syllabus and also developing the Arabic learning syllabus in college.

\footnotetext{
17 Thuimah.

18 Jack C. Richards, Curriculum Development In Language Teaching, International Journal On New Trends In Education And Their Implications (Ijonte), 2013 <Https://Doi.Org/Http://Dx.Doi.Org/10.4135/9780857024428.D4>.
} 


\section{Result and Discussion}

\section{Competency-Based Syllabus}

Arranging a lesson plan is an activity in arranging a program for achieving students' needs. This planning is focused on giving information and guidance to the students for preparing self and arranging the private programs in learning to achieve the learning that has been determined.

According to Salim, he stated that the syllabus is a big line, summary, or the main content or learning material. The syllabus is planning for implementing an interaction in the class. ${ }^{19}$ in education that has basic competence, the syllabus is a learning plan in a course, that contains Standard Competence, Basic Competence, learning material, learning activity, evaluation, time allocation, and learning source. ${ }^{20}$ Learning competence is integration between score aspect and attitude that reflected in form of a thinking activity and action, knowledge aspect and skill. Competence means knowledge, skill, and competence that have been attached to him. By this, an individual able to do effective, cognitive, and psychomotor as well as possible.

Kinds of aspects that contain incompetence concepts are ${ }^{21}$

1. Knowledge is an awareness in cognitive aspect (knowledge mastery)

2. Understanding is a cognitive ability( deep understanding) and affective that someone has.

3. Skills are an individual ability in doing his task.

4. Value is a standard behavior inherent in a person.

5. Attitude is a feeling that is arising from the outside.

6. Interest is a tendency to learn and do something.

The design of competency-based syllabus is a set of plan that includes competence and the achievement in learning that should be had by the learner and consist of the assessment process, learning activity and educational resources for developing syllabus of an educational institution. There are several principles that form in developing the syllabus in an educational institution, including scientific, that appropriate with development, and learning needs, systematic, relevance, consistency, and adequacy.

\footnotetext{
${ }^{19}$ Henry Guntur Tarigan, Dasar-Dasar Kurikulum Bahasa (Bandung: Angkasa, 2009).

20 Ristek Dikti, Modul Pengembangan Ketrampilan Dasar Teknik Instruksional (Pekerti) (Surabaya: Kopertis Vii Surabaya, 2014).

${ }^{21}$ E Mulyasa, Pengembangan Dan Implementasi Kurikulum 2013 (Bandung: Rosda, 2017).
} 
Learning competency refers to the student's ability in some context, students' learning experience, the result of the study, and the ability or competency that obtained from the students that appropriate with the standard through measurable performance. Curriculum-based competence is a competence formula about an expectation that can be known, addressed, and carried out by students in each of levels and can be defined as a description of progress achieved by the students in stages and continuously so that can be said that the students are competent in their fields. The competence in Arabic is a linguistic competence, communicative and social culture. ${ }^{22}$

1. The steps in arranging competence based syllabus. ${ }^{23}$

The process of developing competence based syllabus as follows:

a. Writing the course identity. The course identity needs to write in detail such as the course name, semester and the lecturer.

b. Formulating the competency standard. The competency standard is a statement about attitude, knowledge, and skill that must be achieved by each of the students in learning. Competency standard is a framework that gives an explanation about the basic development of a structured learning program.

c. Determining basic competence.

Basic competency is the detail of competency standard which includes attitude, knowledge, and skills that must be achieved by the students and become a measure of the achievement of competency standard. To get this, an analysis of the competency standard is needed.

d. Determining the main material and the description. The main material in learning must be well arranged so it can support the achievement of the learning competency of a course.

e. Determining the learning experience.

The learning experience is an activity that did by students in learning for achieving the mastery of competency standard, basic ability, and learning material. The learning experience is obtained by the students from the learning activity in the class or outside.

\footnotetext{
${ }^{22}$ Muhbib Abdul Wahab, 'Standarisasi Kurikulum Pendidikan Bahasa Arab Di Perguruan Tinggi Keagamaan Islam Negeri', Arabiyat: Jurnal Pendidikan Bahasa Arab Dan Kebahasaaraban, 2016 <Https://Doi.Org/10.15408/A.V3i1.3187>.

${ }^{23}$ Depdiknas, Buku Pedoman Umum Pengembangan Silabus (Jakarta: Depdiknas, 2004).
} 
f. Describing the competence to be an indicator.

A learning indicator is a basic competency that is measured to determine the achievement of the learning result. Generally, the indicator is formulated by using an operational verb that can be measured and made an instrument of assessment. The indicator of learning outcome achievement in the syllabus serves as a sign of behavior change in a student.

g. Describing indicator in assessment of instrument.

The indicator can be described in the assessment of the instrument in form of types of a bill, the form of instrument, and the example. Each of the indicators can be developed into three assessment of instrument, those are affective, cognitive and psychomotor.

h. Determining time allocation. In designing the syllabus, it should be noted that the right time allocation in achieving the learning objectives. In determining the time allocation it should be noted that the level of difficulties, material coverage and the level of the important material that should be learned.

i. Determining learning source

Learning source is the references/ material that used to arranging the syllabus in form of book, journal and other references used by the teacher in a learning activity in the class or outside. 
2. The format of competence based syllabus

\section{SEMESTER LESSON PLAN}

$\begin{array}{ll}\text { Study Program } & \text { : PGMI } \\ \text { Course } & \text { : Bahasa Arab 1 } \\ \text { Course Code } & : \text { MKDU } \\ \text { Bobot SKS } & : 3 \text { SKS } \\ \text { Semester } & : 1 \\ \text { Lecturer } & :\end{array}$

Standard Competence : The students have four skills in Arabic (Listening, Speaking, Reading and Writing) also knowing the Arabic' Rules.

\begin{tabular}{|c|c|c|c|c|c|c|c|}
\hline $\begin{array}{l}\text { Competency } \\
\text { Standard }\end{array}$ & Basic Competence & $\begin{array}{l}\text { Learning } \\
\text { Material }\end{array}$ & Indicator & Learning Activity & Assessment & $\begin{array}{l}\text { Time } \\
\text { Allocation } \\
\text { (minute) }\end{array}$ & $\begin{array}{l}\text { Learning } \\
\text { Source }\end{array}$ \\
\hline $\begin{array}{l}\text { Listening } \\
\text { Understanding the } \\
\text { oral information in } \\
\text { form of a story or } \\
\text { simple dialog about } \\
\text { greeting an identity }\end{array}$ & $\begin{array}{l}\text { Listening } \\
1.1 \text { Meaning identification of } \\
\text { the utterance appropriate with } \\
\text { the theme by differentiating and } \\
\text { matching the right } \\
\text { identification }\end{array}$ & $\begin{array}{l}\text { Listening } \\
\text { Greeting and } \\
\text { self- } \\
\text { introduction } \\
\text { - The } \\
\text { exposure that }\end{array}$ & $\begin{array}{l}\text { - Matching pictures } \\
\text { with pronunciation } \\
\text { delivered } \\
\text { - Completing sentence } \\
\text { that appropriates with }\end{array}$ & $\begin{array}{l}\text { Listen to } \\
\text { the information that } \\
\text { verbally using the } \\
\text { media. } \\
\text { mufrodat that have }\end{array}$ & kind : & $\begin{array}{l}\text { Introduce } \\
\text { the } \\
\text { alphabet } \\
18 \times 45\end{array}$ & $\begin{array}{l}\text { References: } \\
\text { Book and } \\
\text { media }\end{array}$ \\
\hline
\end{tabular}




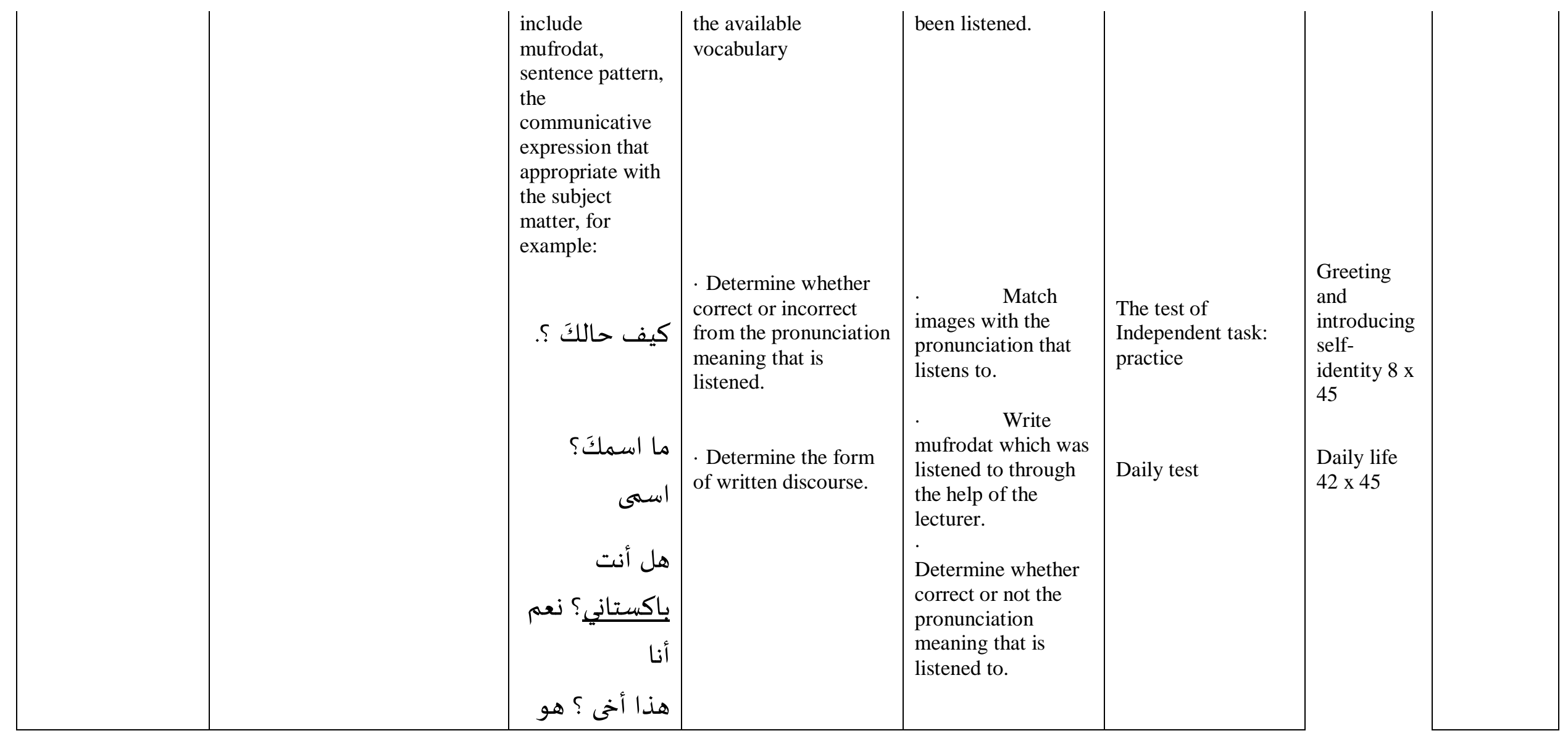




\begin{tabular}{|c|c|c|c|c|c|}
\hline & $\begin{array}{l}\text { 1.2 Obtaining information } \\
\text { through various forms of } \\
\text { simple oral discourse } \\
\text { appropriately. }\end{array}$ & 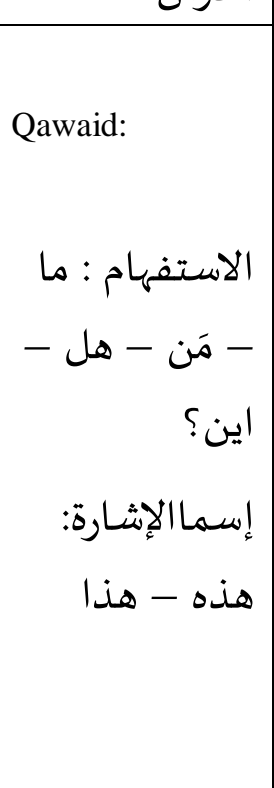 & $\begin{array}{l}\text { BC } 2 \\
\text { - Find out the general } \\
\text { information / the } \\
\text { theme of the discourse } \\
\text { that delivered orally. } \\
\text {. Find out specific } \\
\text { information/ main } \\
\text { sentence from oral } \\
\text { discourse } \\
\text { - Determine the detail } \\
\text { information from the } \\
\text { oral discourse. }\end{array}$ & $\begin{array}{l}\text { Listen to } \\
\text { oral exposure } \\
\text { delivered by the } \\
\text { teacher or through } \\
\text { the media. } \\
\text { Conduct a } \\
\text { group discussion on } \\
\text { the subject. } \\
\text { Write the } \\
\text { conclusion or } \\
\text { content of the } \\
\text { discourse in general. } \\
\text { Present } \\
\text { the discourse. }\end{array}$ & Group task \\
\hline $\begin{array}{l}\text { Pour the } \\
\text { ideas/verbally ideas } \\
\text { of various } \\
\text { information related } \\
\text { to the greeting and } \\
\text { self-identity. }\end{array}$ & $\begin{array}{l}\text { 2.1 Express verbally well and } \\
\text { correctly the information using } \\
\text { the right pronunciation. }\end{array}$ & & $\begin{array}{l}\text { BC } 1 \\
\text { Replicate the } \\
\text { vocabulary or sentence } \\
\text { delivered. }\end{array}$ & $\begin{array}{l}\text { Speaking } \\
\text { Listen to } \\
\text { the information } \\
\text { verbally. }\end{array}$ & $\begin{array}{l}\text { Practice/ } \\
\text { demonstration }\end{array}$ \\
\hline
\end{tabular}




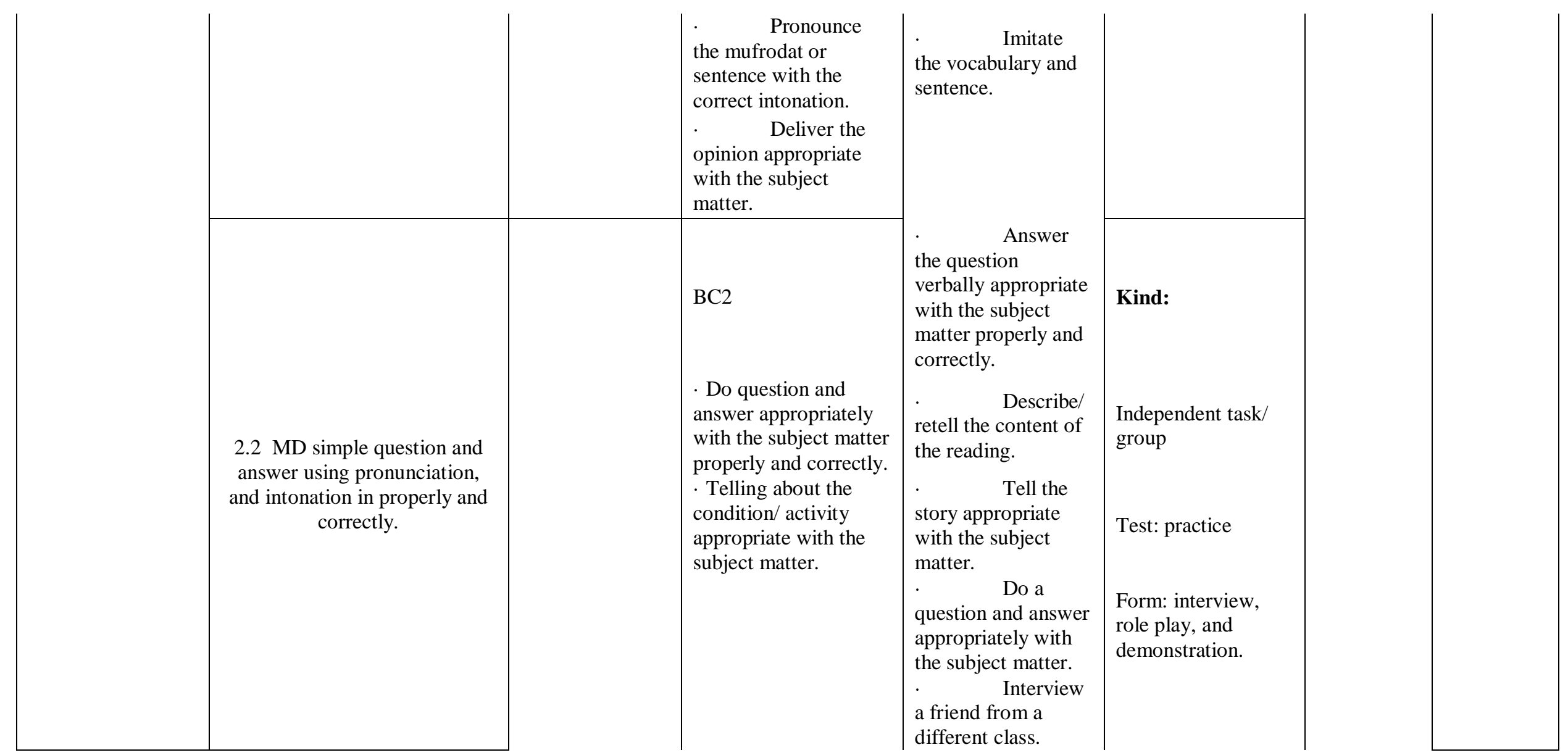




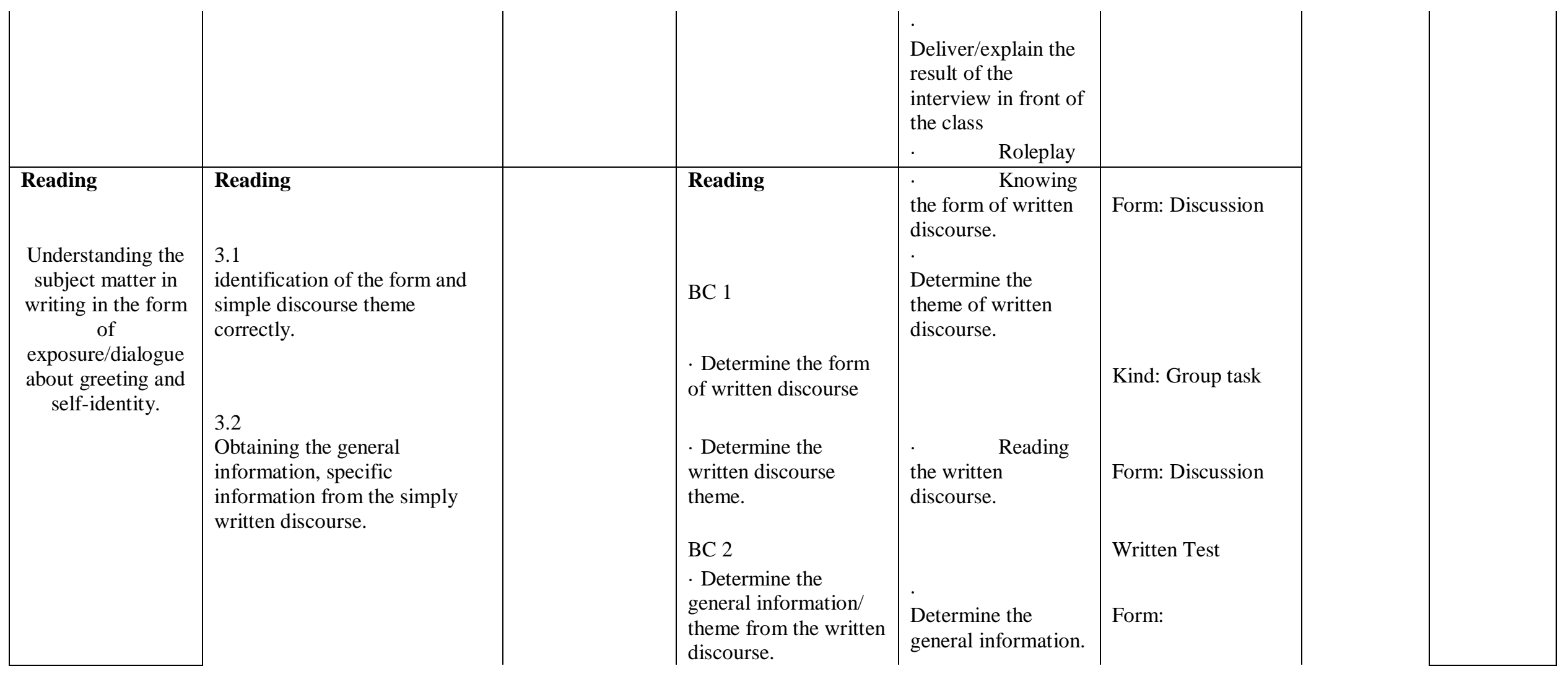




\begin{tabular}{|c|c|c|c|}
\hline & $\begin{array}{l}\text { Determine the } \\
\text { current information/ } \\
\text { keyword from the } \\
\text { written discourse. } \\
\text { - Determine the detail } \\
\text { information from the } \\
\text { written discourse. } \\
\text { - Interpret the meaning } \\
\text { of expression } \\
\text { according to the } \\
\text { subject matter. } \\
\text { - Answer the question } \\
\text { about the current } \\
\text { information from the } \\
\text { written discourse. } \\
\text { Match the written and } \\
\text { the pictures. } \\
\text { - Answer the question } \\
\text { in detail about topic } \\
\text { discussion. }\end{array}$ & $\begin{array}{l}\text { Determine the } \\
\text { specific information } \\
\text { in a group. } \\
\text {. Arranging } \\
\text { random sentences to } \\
\text { be perfect } \\
\text { sentences. } \\
\qquad \text { Answer } \\
\text { the question } \\
\text { appropriate with the } \\
\text { specific information } \\
\text { from the written } \\
\text { discourse. }\end{array}$ & Choose and answer \\
\hline $\begin{array}{l}3.3 \\
\text { Reading aloud of mufrodat and } \\
\text { the sentence in a subject matter } \\
\text { properly and correctly. }\end{array}$ & KD 3 & $\begin{array}{l}\text { Read the } \\
\text { discourse aloud }\end{array}$ & Kind: \\
\hline
\end{tabular}




\begin{tabular}{|c|c|c|c|c|}
\hline & & $\begin{array}{l}\text { - Pronouncing a } \\
\text { word/phrase/sentence } \\
\text { correctly. } \\
\text { - Reading aloud about } \\
\text { mufrodat and sentence } \\
\text { with the correct } \\
\text { pronunciation and } \\
\text { intonation. }\end{array}$ & & $\begin{array}{l}\text { Form: Reading } \\
\text { aloud } \\
\text { Test : practice }\end{array}$ \\
\hline $\begin{array}{l}\text { Expressing ideas } \\
\text { about the subject } \\
\text { matter in written } \\
\text { through simple } \\
\text { exposure/ dialogue. }\end{array}$ & $\begin{array}{l}\text { Writing } \\
\text { 4.1 Write mufrodat, sentence } \\
\text { using alphabet, spelling and } \\
\text { punctuation correctly. }\end{array}$ & $\begin{array}{l}\text { Writing } \\
\text { BC } 1 \\
\text { - Write the vocabulary } \\
\text { correctly. } \\
\text { - Write mufrodat } \\
\text { correctly. }\end{array}$ & $\begin{array}{l}\text { Arranging } \\
\text { mufrodat that cut } \\
\text { randomly to be } \\
\text { sentenced that } \\
\text { appropriates with } \\
\text { the picture. } \\
\text { vocabulary/ } \\
\text { ventence appropriate } \\
\text { with the picture. } \\
\quad \text { Complete } \\
\text { the sentence/ text } \\
\text { using vocabulary } \\
\text { that delivered by the } \\
\text { lecturer. } \\
\text { s } \\
\text { sentence that has } \\
\text { been written on the } \\
\text { board. }\end{array}$ & $\begin{array}{l}\text { Kind: } \\
\text { Independent Task } \\
\text { Test : Written } \\
\text { Form: limited } \\
\text { description }\end{array}$ \\
\hline
\end{tabular}




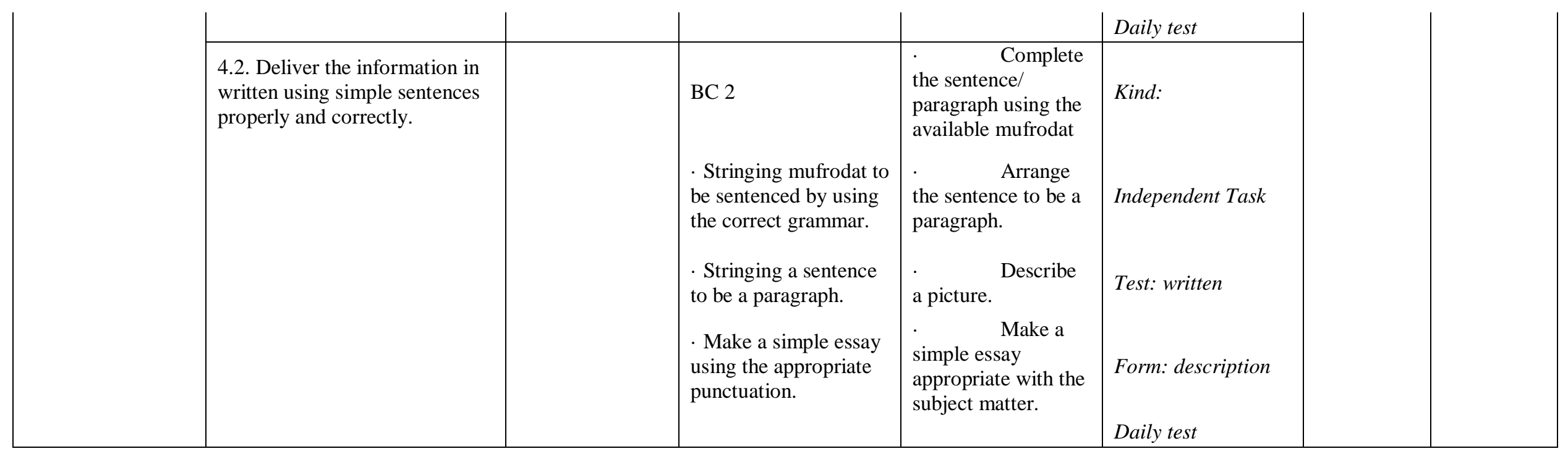


Competency-based syllabus is emphasized the competence aspect which must be had by the students as the final result from learning. Competency Standard in Arabic learning is oriented to the learning about communication activity and respecting humans and their human values. Thus, the learning Arabic in a college is emphasized to improve communication proficiency not mastering the language ability. In this case, language is learned as the support of communication skills. The Arabic learning process is returned to the concept that the students will be able to learn better in the language environment that created naturally. The learning will be more meaningful if the students experience and not just know. Competency-based syllabus gives a big contribution to the potential development of the students based on the principles of constructivism.

Competency-based syllabus requires clear formulation of basic competencies that students must master after participating in learning activities. By using basic competency mastery benchmarks, students avoid unnecessary learning of material, namely material that does not support the achievement of mastery of basic competencies. $^{24}$

a. The competency-based syllabus is to emphasize the achievement of students' competence.

b. The competency-based syllabus is oriented to the learning result and diversity. Submission in learning activity by using various approaches and methods.

c. In a competency-based syllabus, the teacher is not only to be the learning source, but also any source that meets the educational element can be used in learning.

d. The assessment in the competency-based syllabus is emphasized the learning process and also the learning result.

3. The weaknesses of the competency-based syllabus are as follow:

a. The indicator arranged in the curriculum and learning result. The good indicator is arranged by the teacher/lecturer because the teacher or lecturer more understands the students' condition and environment.

\footnotetext{
24 Azkia Muhtarom Albantani, Pengembangan Silabus Ktsp, 2018 <Https://Www.Academia.Edu/12097858/Pengembangan_Silabus_Ktsp>.
} 
b. The concept of competency-based syllabus often changes, so the teacher/lecturer will difficult to design the learning continuously.

c. The teacher's paradigm is still teacher oriented like the previous curriculum.

d. Competence as a single entity.

\section{Skills-based Syllabus}

According to Al-Khuli skills-based syllabus is the syllabus that the learning design is based on the principle of language learning skills that focus on one of the aspects of language skills in each phase of learning. Karl Krahnke (1987: 10) states that "A skill-based syllabus is one in which the content of the language teaching is a collection of specific abilities that may play a part in using language" (skills-based syllabus is a kind of syllabus that contains the specific abilities that become apart from the use of language).

Skills syllabus is organized around different underlying abilities that are involved in using a language for purposes such as reading, writing, listening or speaking. approaching a language through skills is based on the belief that learning a complex activity such aslistening to a lecture involves mastery of a number of individual skills or micro skills that together make up the activity. ${ }^{25}$

The skill-based syllabus has organized the material that related to the academic ability that students need for learning a language. Skill is the things that should be mastered by the students so that they can be said competent in a foreign language. The skill-based syllabus includes linguistic competence (pronunciation, vocabulary, grammar, sociolinguistic and discourse) including listening to spoken language to look for the main idea, write a good and correct paragraph, conveying oral ideas properly and correctly, find out the main ideas, supporters and others. A secondary goal that is likely to develop abilities is more common in language, learning only coincidence with any information that can be available while applying language skills.

\footnotetext{
${ }^{25}$ Hosney.
} 
1. The Format of the skills-based syllabus

Study Program : Pendidikan Agama Islam

Course : Arabic

Code : MKDU

Bobot : $3 \mathrm{Sks}$

Lecturer : :-

Competency Standard: after following this course the students have skills in expressing ideas, feelings, experiences and also the information through the storytelling activity and question answer from the subject matter that appropriate with the Arabic rule properly and correctly.

The brief discussion of the course: Arabic Speaking is the course that gives muhadatsah practice for the students through a paper and available topics.

References :

Silsilatul Ta'limul Lughotil Arabiyah, Al Matawa Al Awal "at-Ta'bir".

Arabiyah Baina Yadaik.

Durus Al-Lughah Al-Arabiyah

Linguaphone: DurusFii Al lughahArabiyah

Arabic Teaching Method 


\begin{tabular}{|c|c|c|c|c|c|c|}
\hline \multirow{2}{*}{ Week } & \multirow{2}{*}{ Course CP } & \multirow{2}{*}{$\begin{array}{l}\text { Learning } \\
\text { Matreial }\end{array}$} & \multirow{2}{*}{$\begin{array}{c}\text { Method/Learning } \\
\text { Strategy }\end{array}$} & \multicolumn{3}{|c|}{ Assesment } \\
\hline & & & & Indicator & Form & Weight $(\%)$ \\
\hline \multirow[t]{4}{*}{1} & \multirow{4}{*}{$\begin{array}{l}\text { Students are able to read the Arabic text } \\
\text { about the journey and understand the } \\
\text { vocabulary. Also able to understanding the } \\
\text { dhomir that is used in the text. (Book: } \\
\text { Silsilatul Arab, p.16) }\end{array}$} & \multirow[t]{4}{*}{ السفر } & Lecture & $\begin{array}{l}\text { 1. Reading aloud about the subject } \\
\text { matter appropriate with the rules of } \\
\text { standard Arabic properly and correctly. }\end{array}$ & \multirow[t]{4}{*}{ Oral test } & \multirow[t]{4}{*}{5} \\
\hline & & & Question answer & $\begin{array}{l}2 . \quad \text { Understanding and able to use } \\
\text { the vocabulary about the procedure of } \\
\text { the journey properly and correctly. }\end{array}$ & & \\
\hline & & & Demonstration & \multirow[t]{2}{*}{$\begin{array}{l}\text { 3. Understanding and identifying } \\
\text { the form of dhomir munfashil (separated } \\
\text { dhomir) dan dhomir muttasil (connected } \\
\text { dhomir). }\end{array}$} & & \\
\hline & & & Practice & & & \\
\hline \multirow[t]{3}{*}{2} & \multirow{3}{*}{$\begin{array}{l}\text { The students can read and able to } \\
\text { understand the Arabic text about } \\
\text { transportation and understand the } \\
\text { vocabulary, and able to understand the } \\
\text { alphabet and make it be Nashab. (Book: } \\
\text { Silsilatul Arab, p.59) }\end{array}$} & \multirow[t]{3}{*}{ واصهلات } & Question answer & $\begin{array}{l}\text { 1. Reading and understanding the } \\
\text { subject matter about transportation that } \\
\text { appropriates with the rules of Arabic } \\
\text { properly and correctly. }\end{array}$ & \multirow[t]{3}{*}{ Oral test } & \multirow[t]{3}{*}{5} \\
\hline & & & Demonstration & $\begin{array}{l}\text { 2. Making a simple dialogue } \\
\text { appropriate with the subject matter by } \\
\text { using the rules of Arabic properly and } \\
\text { correctly. }\end{array}$ & & \\
\hline & & & Practice & $\begin{array}{l}\text { 3. Understanding and identifying } \\
\text { the alphabet which makes the verb } \\
\text { become Nashab }\end{array}$ & & \\
\hline 3 & $\begin{array}{l}\text { The students are able to understand and } \\
\text { master the text about the post office and } \\
\text { understand the vocabulary, also able to } \\
\text { understand the change of } f i \text { ' } i l \text { which is }\end{array}$ & في المكتب & Question Anse & $\begin{array}{l}\text { 1. Making a story about the } \\
\text { activity in the post office by using the } \\
\text { rules of Arabic properly and correctly. }\end{array}$ & Oral test & 5 \\
\hline
\end{tabular}




\begin{tabular}{|c|c|c|c|c|c|c|}
\hline & \multirow[t]{2}{*}{$\begin{array}{l}\text { appropriate with the dhomir munfasil. } \\
\text { (Book: Silsilatul Arab, p.87) }\end{array}$} & & Demonstration & \multirow[t]{2}{*}{$\begin{array}{l}\text { 2. Explaining about the change of } \\
\text { fi'il that appropriate with dhomir } \\
\text { munfasil. }\end{array}$} & & \\
\hline & & & Practice & & & \\
\hline \multirow[t]{4}{*}{4} & \multirow{4}{*}{$\begin{array}{l}\text { The students are able to express ideas } \\
\text { about the hospital theme and the } \\
\text { vocabulary, and also able to understand } \\
\text { about kana wa akhwatuha. (Book Silsilatul } \\
\text { Arab, p.109) }\end{array}$} & \multirow{4}{*}{ المستئ } & Question Anse & $\begin{array}{l}\text { 1. Telling about the rules of } \\
\text { Arabic properly and correctly. }\end{array}$ & \multirow[t]{4}{*}{ Oral test } & \multirow[t]{4}{*}{5} \\
\hline & & & Discussion & $\begin{array}{l}2 . \quad \text { Mentioning the vocabulary } \\
\text { about the hospital that appropriate with } \\
\text { the article. }\end{array}$ & & \\
\hline & & & Demonstration & \multirow[t]{2}{*}{$\begin{array}{l}\text { 3. Explaining about kana wa } \\
\text { akhwatuha. }\end{array}$} & & \\
\hline & & & Practice & & & \\
\hline \multirow[t]{3}{*}{5} & \multirow{3}{*}{$\begin{array}{l}\text { The students are able to pour the ideas } \\
\text { about the theme and the vocabulary, and } \\
\text { also able to understand the time in Arabic } \\
\text { and Ismul Maushul. (Book: Silsilatul Arab, } \\
\text { p.129) }\end{array}$} & \multirow[t]{3}{*}{ في الفندق } & Information search & $\begin{array}{l}\text { 1. Telling about the hotel that is } \\
\text { appropriate with the rules of Arabic } \\
\text { properly and correctly. }\end{array}$ & \multirow[t]{3}{*}{ Oral Test } & \multirow[t]{3}{*}{5} \\
\hline & & & & $\begin{array}{l}2 . \quad \text { Mentioning the vocabulary of } \\
\text { the hotel that those match in the text. }\end{array}$ & & \\
\hline & & & & $\begin{array}{l}\text { 3. Explaining about time in } \\
\text { Arabic and Ismul Maushul. }\end{array}$ & & \\
\hline \multirow[t]{3}{*}{6} & \multirow{3}{*}{$\begin{array}{l}\text { The students are able to express ideas } \\
\text { about the theme and understand about the } \\
\text { Ismul Isyarah. (Book: Silsilatul Arab, } \\
\text { p.153) }\end{array}$} & \multirow{3}{*}{ والوضيوء } & Question Anse & $\begin{array}{l}\text { 1. Expressing ideas that } \\
\text { appropriate with the theme and the rules } \\
\text { of Arabic properly and correctly. }\end{array}$ & \multirow[t]{3}{*}{ Oral Test } & \multirow[t]{3}{*}{5} \\
\hline & & & Demonstration & \multirow[t]{2}{*}{$\begin{array}{l}2 . \quad \text { Explaining about time in } \\
\text { Arabic and Ismul Maushul. }\end{array}$} & & \\
\hline & & & Practice & & & \\
\hline \multirow[t]{2}{*}{7} & \multirow[t]{2}{*}{$\begin{array}{l}\text { The students are able to dialogue with the } \\
\text { theme mosque and understand the } \\
\text { vocabulary and also about the dhomir fi'il } \\
\text { madi. (Book: Silsilatul Arab, hlm.167) }\end{array}$} & \multirow[t]{2}{*}{ في المسجد } & Lecture & $\begin{array}{l}\text { 1. Doing dialogue that appropriate } \\
\text { with the theme and the rules of Arabic } \\
\text { properly and correctly. }\end{array}$ & \multirow[t]{2}{*}{ Oral Test } & \multirow[t]{2}{*}{5} \\
\hline & & & Demonstration & $\begin{array}{l}2 . \quad \text { Mention the vocabulary about } \\
\text { according to what is contained in the }\end{array}$ & & \\
\hline
\end{tabular}




\begin{tabular}{|c|c|c|c|c|c|c|}
\hline & & & & text. & & \\
\hline & & & Practice & $\begin{array}{l}\text { 3. } \\
\text { madi. }\end{array}$ & & \\
\hline \multirow[t]{4}{*}{9 dan 10} & \multirow[t]{4}{*}{$\begin{array}{l}\text { Discussing the subject discussion properly } \\
\text { and correctly. }\end{array}$} & \multirow{4}{*}{ والتعلم } & Lecture & $\begin{array}{l}\text { 1. Understanding the theme that is } \\
\text { presenting by the lecturer. }\end{array}$ & \multirow[t]{4}{*}{ Oral Test } & \multirow[t]{4}{*}{15} \\
\hline & & & $\begin{array}{l}\text { Question and } \\
\text { Answer }\end{array}$ & $\begin{array}{l}2 . \quad \text { Mastering the vocabulary } \\
\text { appropriate with the available subject } \\
\text { discussion. }\end{array}$ & & \\
\hline & & & \multirow[t]{2}{*}{ Discussion } & $\begin{array}{l}3 . \quad \text { Doing question and answer that } \\
\text { is appropriate with the theme. }\end{array}$ & & \\
\hline & & & & $\begin{array}{l}4 . \quad \text { Describing theme properly and } \\
\text { correctly. }\end{array}$ & & \\
\hline \multirow[t]{4}{*}{$\begin{array}{l}11 \text { dan } \\
12\end{array}$} & \multirow[t]{4}{*}{$\begin{array}{l}\text { Doing dialogue that is appropriate with the } \\
\text { subject discussion properly and correctly. }\end{array}$} & & Lecturing & $\begin{array}{l}\text { 1. Understanding the theme that is } \\
\text { presenting by the lecturer. }\end{array}$ & \multirow[t]{4}{*}{ Oral Test } & \multirow[t]{4}{*}{15} \\
\hline & & \multirow[t]{3}{*}{ الشباب } & $\begin{array}{l}\text { Question and } \\
\text { Answer }\end{array}$ & $\begin{array}{l}\text { 2. Mastering the vocabulary that is } \\
\text { appropriate with the subject discussion. }\end{array}$ & & \\
\hline & & & Discussion & $\begin{array}{l}\text { 3. Doing question answer that } \\
\text { appropriate with the subject discussion. }\end{array}$ & & \\
\hline & & & & $\begin{array}{l}\text { 4. Expressing ideas that related to the } \\
\text { subject discussion. }\end{array}$ & & \\
\hline \multirow[t]{2}{*}{$\begin{array}{l}13,14 \\
\text { dan } 15\end{array}$} & \multirow{2}{*}{$\begin{array}{l}\text { Arranging the text of the speech and } \\
\text { presenting according to the theme that has } \\
\text { been determined properly and correctly. }\end{array}$} & \multirow[t]{2}{*}{ الإسلام } & \multirow[t]{2}{*}{ Lecturing } & $\begin{array}{l}\text { 1. Mastering vocabulary that is } \\
\text { appropriate with the subject discussion. }\end{array}$ & \multirow[t]{2}{*}{ Oral Test } & \multirow[t]{2}{*}{25} \\
\hline & & & & $\begin{array}{l}2 . \quad \text { Speech smoothly with good } \\
\text { pronunciation and intonation. }\end{array}$ & & \\
\hline
\end{tabular}


2. The strength of Skill-Based Syllabus

a. This syllabus is effective to develop the students' ability in mastering a type of language, whether it is specific or in a wider scope.

b. This syllabus is easy to accept by the students because it tailored to the needs.

3. The weaknesses of Skill-Based Syllabus

a. Skill-Based Syllabus is not given a skill generally because it more emphasizes in specific aspect from the language skill.

b. Skill-Based Syllabus is only to prepare the students with very limited needs.

\section{Conclusion}

In learning activity, the syllabus has an important role. The syllabus is a learning planning in achieving the learning objectives. The syllabus is a specific description of the learning activity and the presentation of language proficiency based on assumptions and the theories of adopted language. Competency-based syllabus focuses on the competence that must be possessed by all the students. The design of the syllabus that is developed involved some of the competencies in Arabic learning including attitude, knowledge, and psychomotor. Arabic learning is directed to improve communication skills and respect human value. While skill-based syllabus focuses on one of the language skill aspects in each of the learning stages. The skill-based syllabus has organized the material about the ability in using language or academic that is needed in learning the language. This syllabus design can be used as a reference by the language teacher in determining the kinds of learning design that appropriate with the user needs and the target language in learning Arabic.

\section{References}

Abdul Wahab, Muhbib, 'Standarisasi Kurikulum Pendidikan Bahasa Arab Di Perguruan Tinggi Keagamaan Islam Negeri', Arabiyat : Jurnal Pendidikan Bahasa Arab Dan Kebahasaaraban, 2016 <Https://Doi.Org/10.15408/A.V3i1.3187>

Al-Khuli, Muhammad Ali, A Dictionary Of Applied Linguistics: English-Arabic With An 
Arabic-English Glossary, 1st Edn (Lebanon: Librairie Du Lian, 1986)

Albantani, Azkia Muhtarom, Pengembangan Silabus Ktsp, 2018

<Https://Www.Academia.Edu/12097858/Pengembangan_Silabus_Ktsp>

Bani, 'Pengembangan Silabus Dan Rencana Pelaksanaan Pembelajaran Dalam

Meningkatkan Profesionalisme Guru', Jurnal Pendidikan, Komunikasi, Dan

$\begin{array}{lllll}\text { Pemikiran } & \text { Hukum } & \text { Islam, } & 6.2 & \text { (2015), }\end{array}$

<Https://Ejournal.Iaida.Ac.Id/Index.Php/Darussalam/Article/View/73>

Depdiknas, Buku Pedoman Umum Pengembangan Silabus (Jakarta: Depdiknas, 2004)

Fahrurrozi, Aziz, 'Pembelajaran Bahasa Arab: Problematika Dan Solusinya', Arabiyat:

Jurnal Pendidikan Bahasa Arab Dan Kebahasaaraban, 2015

<Https://Doi.Org/10.15408/A.V1i2.1137>

Harmer, Jeremy, The Practice Of English Language Teaching (Harlow Essex: Pearson Education Limited, 2001)

Hosney, Mariana Ulfah, 'From Syllabus To Curriculum Development', Jurnal Linguistik Terapan, 3.1 (2013) <Https://Jlt-Polinema.Org/?P=379>

Madjid, Abdul, And Chaerul Umam, Pendekatan Ilmiah Dalam Implementasi Kurikulum 2013 (Bandung: Pt. Remaja Rosda Karya, 2015)

Mulyasa, E, Pengembangan Dan Implementasi Kurikulum 2013 (Bandung: Rosda, 2017)

Nurdin, Syafruddin, 'Pengembangan Kurikulum Dan Rencana Pembelajaran Semester

(Rps) Berbasis Kkni Di Perguruan Tinggi', Al-Fikrah: Jurnal Manajemen Pendidikan, 2019 <Https://Doi.Org/10.31958/Jaf.V5i1.813>

Nurhayati, 'Pengembangan Silabus Pembelajaran Bahasa Indonesia Untuk Sekolah Menengah Pertama Di Kota Palembang', 91 (2017), 399-404

Richards, Jack C., 'Curriculum Approaches In Language Teaching: Forward, Central, $\begin{array}{llll}\text { And Backward Design', Relc Journal, } 2013 & \end{array}$ <Https://Doi.Org/10.1177/0033688212473293>

_- Curriculum Development In Language Teaching, International Journal On New Trends In Education And Their Implications (Ijonte), 2013 <Https://Doi.Org/Http://Dx.Doi.Org/10.4135/9780857024428.D4>

Ristek Dikti, Modul Pengembangan Ketrampilan Dasar Teknik Instruksional (Pekerti) (Surabaya: Kopertis Vii Surabaya, 2014)

Sagala, Syaiful, 'Silabus Sebagai Landasan Pelasanaan Dan Pengembangan Pembelajaran Bagi Guru Yang Profesional', Tabularasa, 5.1 (2008), 11 
<Http://Digilib.Unimed.Ac.Id/714/>

Suratmi, 'Penelitian Dan Pengembangan Silabus Bahasa Inggris Program Studi Penerbitan', Jurnal Publipreneur, $2.4 \quad$ (2014), $115 \quad$ <Https://TextId.123dok.Com/Document/Yjoewxmz-Penelitian-Dan-Pengembangan-SilabusBaha-2.Html>

Syaifullah, Muhammad, 'Kajian Teoritis Pengembangan Bahan Ajar Bahasa Arab', Arabiyatuna Jurnal Bahasa Arab, $3.1 \quad$ (2019), 127-44 <Https://Doi.Org/Http://Dx.Doi.Org/10.29240/Jba.V3i1.764>

Tarigan, Henry Guntur, Dasar-Dasar Kurikulum Bahasa (Bandung: Angkasa, 2009)

Thuimah, Rusdi Ahmad, Ta'lim Al Arabiyah Li Ghairi An Nathiqiina Biha Wa Asaliibihi (Ar Ribath: Mansuuratu Al Munadhamah Al Islamiyyah Lii At Tarbiyah Wa Al'ulum Wa Atsaqofah, 1989)

Zubaidi, Ahmad, 'Model-Model Pengembangan Kurikulum Dan Silabus Pembelajaran Bahasa Arab', Cendekia: Jurnal Kependidikan Dan Kemasyarakatan, 2016 <Https://Doi.Org/10.21154/Cendekia.V13i1.240>

الصقري, محمد بن خلفان, ، ، تعليم اللغة العربية للناطقين بغير ها من خلال ثقافتها، تجربة كلية السلطان قابوس تعليم اللغة العربية للناطقين بغير ها-سلطنة عمان (Malang: Imla, 2015), P. 1 